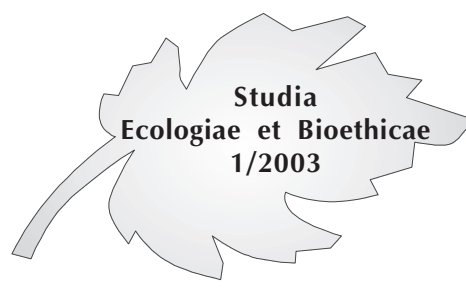

Marek HALINIAK*

\title{
Filozoficzne aspekty modelowania cybernetycznego w metodologii działań politycznych w zakresie zrównoważonego rozwoju
}

\begin{abstract}
Wprowadzenie
Analiza dyskusji dotyczących pojęcia "sustainable development"1 czyli problemu trwałości ludzkiej cywilizacji zdominowana została w Polsce przez aspekty ekologiczne, ekonomiczne i prawne, co w zasadzie jest odzwierciedleniem struktury debaty międzynarodowej. Wydaje się jednak, iż stosunkowo mało miejsca poświęca się metodologii i szeroko rozumianej problematyce prakseologicznej związanej z tworzeniem i wdrażaniem równoważonego rozwoju. W szczególności dotyczy to aspektów związanych $\mathrm{z}$ modelowaniem cybernetycznym lub systemowo-informacyjnym jako instrumentem formułowania strategii politycznych. W konsekwencji problematyka równoważonego rozwoju przenika do prawa głównie poprzez takie systemy normatywne jak moralność, aksjologia czy system norm politycznych. Tym samym sprowadzana jest w znacznym zakresie do dyskusji na temat wartości. Jest to oczywiście bardzo istotny element kształtowania się systemu "sustainable development", jednak brak zrównoważenia poszczególnych obszarów debaty może prowadzić do segmentyzacji i ideologizacji całej problematyki w stopniu spowalniającym znacznie możliwość przełożeń na sferę konkretnych działań instytucjonalnych. Z drugiej strony modelowanie staje się istotnym instrumentem wspierania decyzji politycznych, o czym świadczą nie tylko wyniki przedsięwzięć międzynarodowych podejmowanych w ramach ONZ czy $\mathrm{UE}^{2}$, lecz praktyka państw wysokorozwiniętych.
\end{abstract}

\footnotetext{
Ministerstwo Środowiska.

1 Spośród wielu wypracowanych w ciągu ostatnich kilkunastu lat definicji tego pojęcia z najwłaściwszą uznaję definicję i interpretację wynikającą z dokumentów końcowych Szczytu Ziemi w Johannesburgu, potwierdzającą rozwój społeczny, jak i rozwój gospodarczy, a także ochronę środowiska jako trzy współzależne składowe zrównoważonego rozwoju.

2 Raporty „Global Environmental Outlook” przygotowywane przez ONZ. Ostatni z nich GEO -3 oprócz przedstawienia stanu świata przez trzy ostatnie dekady zawiera prognozę na lata
} 
W tym kontekście warto przypomnieć, iż początki polskiej dyskusji na temat równoważenia rozwoju $\mathrm{w}$ aspekcie ekonomicznym, społecznym i ekologicznym cechował wysoki stopień świadomości co do znaczenia podejścia systemowo-cybernetycznego ${ }^{3} \mathrm{w}$ odniesieniu do planowania zrównoważonego rozwoju. Znalazło to wyraz w kilku publikacjach lat 80, czego przykładem jest praca R. Kozioła "Metody systemowe w aspekcie planowania Ekorozwoju"4 ${ }^{\prime \prime}$. Właśnie aspekty metodologiczne i prakseologiczne $\mathrm{w}$ odniesieniu do planowania rozwoju były głównym instrumentem włączania problematyki ekologicznej do planowania strategicznego. Inspirującą rolę $\mathrm{w}$ tym zakresie odegrał przygotowany na zlecenie Klubu Rzymskiego przeszło 30 lat temu tkz. „model Medowsów” oraz cały szereg kolejnych instrumentów służących racjonalizacji planowania strategicznego.

\section{Cybernetyka jako nauka społeczna}

Nie ulega wątpliwości, iż podstawą modelowania jako narzędzia politycznego był rozwój cybernetyki i rozpowszechnienie się w naukach społecznych jej podstawowych paradygmatów. Warto w tym kontekście zwrócić uwagę na semantykę i historię kształtowania się pojęcia "cybernetyka", która przedstawiona została przez M. Mazura w pracy "Społeczne znaczenie cybernetyki". Wyraz ten pochodzi od greckiego słowa „kybernetiken", co pierwotnie oznaczało umiejętność kierowania, a słowo „kybernetes - „sternika okrętu". W tym aspekcie cytowany jest fragment dialogów Platona, gdzie Sokratesowi przypisywane jest stwierdzenie: „Cybernetyka chroni od największych niebezpieczeństw, nie tylko dusze, lecz również ciała i dobytek". W tym kontekście koncepcja cybernetyki jako dyscypliny nie jest odległa od filozofii rozumianej jako nauki o „mądrości życia". W dzisiejszym rozumieniu można by powiedzieć, iż funkcje cybernetyki obejmowały najważniejsze, gdyż decydujące o strategicznych konsekwencjach elementy edukacji, etyki, zarządzania, zdrowia oraz ekonomii. Tym samym cytowane stwierdzenie uznać można za traf-

2002-2032 wg czterech scenariuszy. Interesująca jest też propozycja grupy filozofów kontynuujących prace Leo Apostola. W ramach programu „Principia Cybernetica Projekt” opracowali oni cybernetyczny model obrazu świata.

3 Bardziej adekwatne wydaje się sformułowanie „systemowo-informacyjne” wg systematyki zaproponowanej przez Profesora J. Dołegę w „Ekofilozofia jako ujęcie systemowo-informacyjne ekorozwoju" str 32 w Ochrona środowiska społeczno-przyrodniczego w filozofii i teologii, redakcja Jozef Dołega WUKSW Warszwa 2001.

4 Materiały z Konferencji PKE. Prace naukowe okręgu Małopolska. Tom 3, Wydawnictwo AGH, Kraków, 1986. 
ne określenie warunków, jakie spełniać powinna prawidłowo konstruowana strategia polityczna. Takie znaczenie terminu "cybernetyka" funkcjonowało jeszcze w wieku XIX. Ampére ${ }^{5}$ definiuje cybernetykę jako metodologię rządzenia. Podobnie pojęcie to definiowali inni autorzy ${ }^{6}$. Również XX wieczne definicje wyraźnie wiążą cybernetykę ze sterowaniem jako elementem zarządzania. Wskazuje na to już sam tytuł klasycznej pracy twórcy współczesnej cybernetyki N. Wienera "Cybernetyka, czyli komunikacja $i$ sterowanie w zwierzęciu i maszynie". Jakkolwiek koncentracja na „zwierzęciu i maszynie” nie obejmuje kwestii społecznych, to bardzo szybko się okazało jasne, że technologie cybernetyczne odgrywają zasadniczą rolę w sterowaniu "machiną społeczną". Właśnie takie ujęcie cybernetyki - czyli nauki o ogólnych zasadach sterowania - jest najbardziej rozpowszechnione ${ }^{7}$, a szereg jej paradygmatów przeniesionych zostało do poszczególnych nauk szczegółowych stanowiąc wspólną płaszczyznę analiz. Przykładem tego zjawiska była W.R. Ashby'ego koncepcja „Homeostatu" przedstawionego jako konstrukcja zespołu kilku sprzężonych z sobą regulatorów, zespołu niezwykle odpornego na zakłócenia zewnętrzne. Założenia teorii homeostatu z równym powodzeniem wykorzystane zostały $\mathrm{w}$ całej gamie nauk od biologii poprzez medycynę, aż po ekonomię i politologię. W szczególności posłużyły do falsyfikacji koncepcji wolnego rynku jako układu homeostatycznego w sytuacji zakłócenia mechanizmów współdziałania obwodów regulacyjnych. Innym przykładem, który świadczy o roli cybernetyki w rozwoju innych szczegółowych dyscyplin jest pojęcie "sprzężenia zwrotnego".

Z punktu widzenia celów niniejszego opracowania ważne jest podkreślenie korelacji pomiędzy rozwojem cybernetyki, a rozwojem nauk o zarządzaniu. Chodzi tutaj w szczególności o rozwój technik wspomagających podejmowanie decyzji, które bardzo silnie rozwinęły modelowanie strategicznych, dalekosiężnych konsekwencji systemowych. Okazało się, że właśnie ten rodzaj decyzji ma decydujące znaczenie dla procesu dostosowywania się poszczególnych podsystemów, co przesądza o ich zdolności do przetrwania. W konsekwencji pojawiło się zapotrzebowanie na strategiczne analizy systemowe dotyczące efektywności organizacyjnej oraz możliwości jej usprawniania, które zapewnić mogły szerokie, interdyscyplinarne zespoły eksperckie. To stosunkowo nowe zjawisko stało się powszechne zarówno $\mathrm{w}$ dużych instytucjach sektora prywatnego jak i publicznego. Jest to drugi powód (poza wspomnianym rozprzestrzenieniem się paradygmatów cybernetycznych), dla którego cyberne-

\footnotetext{
AMPÉRE, Esej o filozofii nauki, 1834.

Trentowski B., Stosunek filozofii do cybernetyki, czyli sztuka rzqdzenia narodem, 1843.

7 W.R. AshbY'Ego - w książce Wstęp do cybernetyki z 1956 r. ; C.E. SHAnnona, Matematyczna teoria komunikacji, 1948.
} 
tyka traktowana jest jako nauka o charakterze interdyscyplinarnym. Charakterystyczną cechą tej interdyscyplinarności jest fakt, iż obejmuje ona zarówno nauki matematyczno-przyrodnicze jak i nauki społeczne. Pod względem zakresu oddziaływania jest nauką zbliżoną do filozofii. Na tym tle charakteryzuje się jednak wysokim poziomem konkretyzacji i możliwością szerokich, bezpośrednich zastosowań. W odróżnieniu od filozofii cybernetyka jest jednak jednowymiarowa i niepełna. Tym samym jej efektywność bezpośrednio zależy od przyjętych założeń filozoficznych, w szczególności tych z zakresu epistemologii, aksjologii oraz etyki. Wtórna rola cybernetyki wobec filozofii dotyczy zwłaszcza nauk społecznych, w tym teorii zarządzania. Dobrze uzasadnione modele cybernetyczne dostarczyły przekonujących argumentów pozwalających na analizę interakcji wewnątrzsystemowych oraz ich wpływu na wyznaczanie kierunku, w którym system zmierza jako całość. Szczególne znaczenie cybernetyki wynika również z faktu, iż wprowadzenie jej podstawowych modeli do nauk społecznych zrewidowało metodologię prognozowania zjawisk, a poprzez odrzucenie zasady prostej ekstrapolacji przyczyniło się zarówno do zmniejszenia poziomu zagrożenia w pewnych obszarach, jak i zwiększenia świadomości zagrożeń w innych.

Konsekwencją interdyscyplinarnego charakteru cybernetyki jest cechujący się abstrakcyjnością i ogólnikowością rodzaj stosowanych terminów. Podstawową rolę w tym zakresie odgrywa "system”, czyli przedmiot analizy wszelkich obiektów. Jest on definiowany jako „zbiór elementów i występujących między nimi relacji". Warto podkreślić, iż poziom abstrakcji tego pojęcia jest tak wysoki, iż dorównuje filozoficznym pojęciom „logos" "byt” czy "materia”. Ma ponadto tę zaletę, iż poprzez dodanie przedrostka „-pod" lub ,-nad" można określić skomplikowane relacje w stosunku do innych obiektów i zobrazować proces ich wzajemnego "przenikania się". Tradycyjnie przyjmuje się, iż cybernetyka nie stawia kwestii ontologicznych, a koncentruje się na ujęciu funkcjonalnym. Pod tym względem zakres analizy cybernetycznej jest niezwykle zawężony $\mathrm{w}$ porównaniu $\mathrm{z}$ ujęciem filozoficznym. Tym niemniej metody cybernetyczne okazują się przydatne dla analizy koncepcji ontologicznych - nawet wówczas, kiedy kwestia dotyczy relacji zachodzących pomiędzy systemem "tego co jest", a systemem "tego czego nie ma" ${ }^{8}$. Z drugiej strony warunki ogólne, które powinien spełniać system (określoność, niezmienność, rozłączność, kompletność) powinny uzasadniać sceptycyzm $\mathrm{w}$ stosowaniu metodologii systemowej, zwłaszcza w naukach społecznych. Chodzi tutaj o oczywistą niemożność całkowitego spełnienia poszczególnych kryteriów, w rezultacie czego cybernetyczne modele $\mathrm{w}$ obszarze nauk społecznych są znacznie

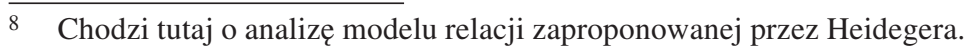


mniej „obiektywne" niż w naukach matematyczno-przyrodniczych. Z drugiej strony odgrywają one znacznie większą rolę w konstruktywistycznym modelu poznania ${ }^{9}$. Dlatego bardzo aktualny jest sformułowany przez K. Poppera postulat falsyfikacji, jako podstawowe kryterium określenia obszarów, gdzie zastosowanie danego modelu jest, a gdzie nie jest skuteczne (empirycznie sprawdzalne).

\section{Cybernetyka a teorie systemów}

Należy zwrócić uwagę, że zaprezentowana powyżej koncepcja cybernetyki jako pochodnej od filozofii dyscypliny ogólnej stoi w sprzeczności z poglądami podporządkowującymi cybernetykę dyscyplinie określanej jako teoria systemów. W polskiej literaturze naukowej podejście systemowe $\mathrm{w}$ kategoriach filozoficznych najpełniej ujęte zostało $\mathrm{w}$ pracy $\mathrm{M}$. Lubańskiego ${ }^{10}$. Autor przedstawił filozoficzną genezę teorii systemów, podstawowe kierunki badań, a także krytyczną analizę podstawowych terminów: system, otoczenie systemu, wejścia i wyjścia systemu, informacja, zasilanie. Szczególnie interesujące są rozważania autora na temat relacji między teoriami systemów a cybernetyką. $W$ tym miejscu należy zaznaczyć, że pojęcie "teoria systemów" po raz pierwszy użyte zostało w końcu lat dwudziestych w pracach biologa L. von Bertalanffy'ego i zaproponowane zostało jako propozycja nowego podejścia do organizmów żywych. $Z$ czasem przeniesione zostało do większości nauk zarówno matematyczno-fizycznych jak i społecznych. M. Lubańskiego zwraca uwagę, na występujący w literaturze przedmiotu spór polegający na tym, że ,jedni autorzy szeroko rozumiejąc teorie systemów zaliczaja do niej cybernetykę, dru$d z y$ - szeroko rozumiejac termin cybernetyka właczaja do niej teorie systemów". Należy zwrócić uwagę, że argumenty przemawiające za uznaniem teorii systemów jako dyscypliny obejmującej również cybernetykę są wystarczające, aby każdą inną naukę - włączając w to filozofię uznać za część teorii systemów. To nieporozumienie związane $\mathrm{z}$ traktowaniem cybernetyki jako części teorii systemów wynika z historii rozwoju cybernetyki jako dyscypliny, która z nauk matematyczno-przyrodniczych uzyskała zastosowanie w naukach społecznych. $\mathrm{W}$ takim ujęciu cybernetyka postrzegana była poprzez szeroki pryzmat funkcjonalności, jakie jej podstawowe paradygmaty spełniały $\mathrm{w}$ poszczególnych dyscyplinach. W ujęciu tym nie uwzględniana jest rola cybernetyki jako nauki łączącej poszcze-

9 A. Zybertowicz, Przemoc i poznanie. Studium z nieklasycznej socjologii wiedzy, Toruń: UMK 1995.

10 M. Heller, M. Lubański, S. W. Ślaga, Zagadnienia filozoficzne wspótczesnej nauki. Wstęp do filozofii przyrody, wyd. 4, Wydawnictwo ATK, Warszawa, 1992. 
gólne dyscypliny między sobą (ujęcie poziome) oraz z filozofią (ujęcie pionowe). Ponadto analiza cybernetyczna jest analizą dopuszczającą równowartość analizy „od szczegółu do ogółu” oraz "od ogółu do szczegółu", podczas gdy teorie systemów z góry zakładają ich istnienie, co budzi poważne wątpliwości zarówno natury ontologicznej jak i epistemologicznej.

W literaturze przedmiotu spotkać można opinie różnicujące cybernetykę i teorie systemów w zależności od relacji łączącej podmiot $\mathrm{z}$ przedmiotem poznania. Przykładem jest opinia R. Kozioła, który stwierdza „Ogólna teoria systemów podkreśla z jednej strony autonomię funkcjonowania systemów, z drugiej zaś - indukcyjne oddziatywanie ich na siebie. Natomiast cybernetyka traktuje dziedzine relacji "człowiek biosfera" jako pewien system sterowania, w którym centralnym regulatorem jest człowiek (społeczeństwo)11". Wydaje się, iż zaprezentowany argument $\mathrm{w}$ żaden sposób nie świadczy o bardziej ogólnym charakterze teorii systemów w relacji do cybernetyki. W tym kontekście można by stwierdzić, iż teorie systemów stanowią jedną z dyscyplin szczegółowych wchodzącą w skład cybernetyki jako nauki ogólnej. Wynika to z samej definicji nauki jako działalności zorganizowanej i celowej. W przypadku cybernetyki uzasadnieniem tym jest możliwość wpływania na procesy rozwojowe przez człowieka, co potwierdza również społeczny potencjał tej nauki. Warto podkreślić, że takie rozumienie cybernetyki wprost odwołuje się do prezentowanej etymologii słowa - sterowania.

Zwrócić należy uwagę na rozbieżności definicyjne odnoszące się do terminu "model”. Lubański proponując definicję zaproponował typologię modeli dzieląc je na fizyczne i symboliczne. Wydaje się, że głównym argumentem przemawiającym za takim (zresztą niedychotomicznym) podziałem była przede wszystkim potrzeba uporządkowania terminologii oraz uniknięcia błędów interpretacyjnych wynikających z wieloznaczności. Przenikanie paradygmatów cybernetycznych do nauk społecznych i związana z tym moda na używanie tego terminu uczyniła z niego swoiste "słowo wytrych" wpisując je na długą listę najczęściej używanych i najbardziej nieostrych pojęć. Kolejna klasyfikacja przedstawiona została w pracy Grzegorza Bugajaka ${ }^{12}$, który wyróżnił cztery podstawowe znaczenia terminu "model”, przyjmując jednocześnie za podstawę podział na "model abstrakcyjny” i "model jednostkowy”. Analizując literaturę pod kątem prawidłowości i uzasadnienia stosowania tego terminu wydaje się

11 Materiały z Konferencji PKE. Prace naukowe okręgu Małopolska. Tom 3, Wydawnictwo AGH, Kraków, 1986.

12 G. BUGAJAK, Model Wielkiego Wybuchu, wybrane aspekty metodologiczne i symulacyjne, w: http://www.sssg.ae.krakow.pl/sssgdaw/a98/teksty/tresc.htm 
zasadnym, aby przynajmniej w tych opracowaniach, dla których ma on istotne znaczenie prezentowane były definicje. Jest to uzasadnione doświadczeniami płynącymi z rozwoju wielu nauk społecznych, a w szczególności socjologii, której naukowy charakter kwestionowany jest przede wszystkim ze względu na brak chociażby jednego, wspólnego dla całej dyscypliny terminu (wspólnota, organizacja, instytucja....) ${ }^{13}$.

Ważna analiza "myślenia systemowego" w fizyce przeprowadzona została przez M. Tempczyka ${ }^{14}$. Odwotując się do prac L. von Bertalanffy'ego zwrócit on uwagę, że analiza w kategoriach systemów uzasadniona jest w istocie natura rzeczy wynikajaca z samego faktu jej zorganizowania. Dla zobrazowania tej tezy przytaczane jest uzasadnienie Bertalanffy'ego "Ponieważ podstawowa cecha istoty żywej jest jej organizacja, tradycyjne metody badania poszczególnych elementów i procesów nie moga dać petnego objaśnienia zjawisk życia. Badania takie nie daja żadnej informacji o koordynacji poszczególnych części i procesów. Dlatego też głównym zadaniem biologii musi być odkrywanie praw, które rzadza systemami biologicznymi (na wszystkich poziomach organizacji). Sądzimy, że próby znalezienia podstawy dla biologii teoretycznej prowadza do zasadniczej zmiany obrazu świata. Poglad ten jako podstawe metody badan nazwiemy biologia organizmalna, a jako próbę objaśniania zjawisk - systemowa teoria organizmu". Zaprezentowany cytat obrazuje moment przejścia zaczerpniętego z fizyki paradygmatu systemu do nauk biologicznych. Przedstawione argumenty dotyczą relacji pomiędzy analizą i syntezą. Są niejako naturalną reakcją na będący konsekwencją ujęcia newtonowskiego redukcjonizm. Odzwierciedla jednocześnie ważny etap w rozwoju nauki, który dosyć przekonująco opisany został przez F. Caprę ${ }^{15}$. Zaznaczyć jednak należy, że rozwój „koncepcji antyredukcjonistycznej", poprzez szereg uproszczeń doprowadził do częściowego zniekształcenia, a wręcz ideologizacji problemu ${ }^{16}$. Tym niemniej wyjście poza ramy metodologii kartezjańskiej w kierunku ujęć systemowych, co w wieku dwudziestym stało się udziałem całej nauki, jest zjawiskiem o trudnych do przecenienia konsekwencjach. Należy podkreślić, iż są to konsekwencje zarówno pozytywne jak i negatywne. W kontekście niniejszej pracy istotnym jest podkreślenie, że rozpowszechnienie się koncepcji systemowych nie tylko w nauce, lecz praktyce życia społecznego na drugi plan odsuwa obiektywnie sprawdzalną rzeczywistość na rzecz wyobrażeń o tej rzeczywistości. W konsekwencji wraz z Kartezjuszem, Baconem, i Newtonem traci znaczenie obiektywistyczny model poznania na rzecz modelu konstruktywistycznego. Same modele stają się

13 K.Z. Sowa, Wstęp do socjologii zrzeszeń. Warszawa: PWN 1988.

14 M. ТемРсZYк, Fizyka a swiat realny. Elementy filozofii fizyki”. PWN 1986.

15 F. CAPra, Punkt zwrotny,. Warszawa 1987.

16 Zjawisko to jest szczególnie wyraźne w głównym nurcie ideologii „New Age”, którego F.Capra jest jednym z czołowych przedstawicieli. 
natomiast instrumentem w walce o „rzeczywistość" - rozumianą nie dosłownie, lecz jako sposób jej postrzegania. W tym kontekście społeczne zagrożenia wynikają z podstawowej negatywnej cechy modelowania i systematyzowania jaką jest uproszczenie. O ile na gruncie nauki, przy zachowaniu odpowiedniego poziomu dyscypliny cecha ta jest zaletą, to na gruncie polityki konsekwencje mogą być nieobliczalne. Wskazywało na to - w innym nieco kontekście - wielu teoretyków, a wiek dwudziesty dostarczył wielu tragicznych potwierdzeń praktycznych. Zaznaczyć należy, iż nie chodzi tutaj o to, że przed przełomem einsteinowskim $\mathrm{w}$ rzeczywistości społecznej nie funkcjonowały „modele uproszczen". Analitycznie, a nawet redukcjonistycznie ukierunkowana nauka, poprzez koncentrację na szczególe sprzyjała społecznemu odrzucaniu uproszczeń. Dominacja syntezy nad analizą takim uproszczeniom sprzyja. $Z$ tej perspektywy istotnym jest, aby cybernetyczne modelowanie zrównoważonego rozwoju uwzględniało relacje pomiędzy analizą i syntezą $w$ warunkach tworzącego się globalnego społeczeństwa informacyjnego. W tej perspektywie uznać należy, że stosowanie metod cybernetycznych w planowaniu politycznym, poprzez możliwość uwzględnienia olbrzymiej liczby zmiennych sprzyja przywróceniu równowagi w proporcjach pomiędzy syntezą i analizą. W ten sposób - poprzez wspomaganie procesów decyzyjnych - bezpośrednio oddziałuje na kształtowanie rzeczywistości społecznej bez popadania w determinizm.

Oddzielając kwestię naukowych uzasadnień wyodrębniania teorii systemów jako oddzielnej dyscypliny i jej relacji z cybernetyką zaznaczyć należy praktyczne zastosowania jej instrumentów do integracji różnorodnych systemów. W szczególności (abstrahując od poprawności uzasadnień naukowych) narzędzia teorii systemów przydatne są w konstruowaniu strategii politycznych łączących w całość poszczególne aspekty rzeczywistości. Zjawisko to $\mathrm{w}$ języku przeniesionym $\mathrm{z}$ teorii systemów do polityki określić można jako symboliczną integrację podsystemów w system. W tej perspektywie zrównoważony rozwój jest systemem składającym się z trzech filarów (podsystemów) - społeczeństwo, gospodarka, ekologia. Kontekst ten wskazuje nie tylko na postulowaną potrzebę zrównoważenia tych trzech zasadniczych elementów rozwoju w ich wzajemnej relacji między sobą, lecz również - co tutaj istotne - postuluje potrzebę upodobnienia struktur poszczególnych podsystemów w sposób zapewniający trwałość systemu jako całości. W najdalej idącym wariancie sprowadza się to do dostosowania społeczeństwa oraz gospodarki do struktur podsystemu ekologicznego. 
Filozoficzne aspekty modelowania cybernetycznego w metodologii dziatań politycznych...

\section{Rozwój modelowania jako instrumentu wspomagania działań politycznych}

Aspekt zrównoważonego rozwoju jest widoczny w modelowaniu działań politycznych już od czasu powstania pierwszych modeli. Wskazuje na to zastosowana przez J.W. Forrestera metoda "dynamiki systemów", zastosowana następnie przez zespół Medows'ów. Metoda ta była podstawą badań zmian w kondycji światowej społeczności i jej środowiska przyrodniczego, a rezultatem jej zastosowania było opracowanie prognoz ostrzegawczych dla Klubu Rzymskiego ${ }^{17}$. Znajduje ona bezpośrednie odzwierciedlenie również $\mathrm{w}$ sformułowanych na podstawie ostrzeżeń postulatach zmian $\mathrm{w}$ polityce społeczno-gospodarczej i ekologicznej ${ }^{18}$ - w założeniach globalnej strategii politycznej. Za najbardziej istotne elementy stworzonego przez Medowsów modelu uznać należy samo jego sformułowanie w sposób dający się przełożyć na język działań politycznych oraz stworzenie przekonującej wizji, w której społeczeństwo, gospodarka i środowisko stanowią spójny, współzależny i potencjalnie trwały system. Wielu krytyków podkreśla ograniczony poziom sprawdzalności sformułowanych wówczas zagrożeń, przy czym zaznaczyć należy, że chodzi tutaj o błędy dotyczące dynamiki, lecz nie samego kierunku rozwoju zagrożeń. Przegląd wybranych modeli w zakresie zrównoważonego rozwoju zawarty został w oficjalnej publikacji UE - „Cloudy crystal balls. An assesment of recent European and global scenerio studiem and models". We wstępnej części poświeconej metodologii zaprezentowano opis stanu studiów nad modelami i scenariuszami jako podstawowymi narzędziami formułowania, realizacji i oceny strategii politycznych realizowanych przez UE. Należy zwrócić uwagę, iż autorzy opracowania podkreślają prognostyczne ograniczenia modelowania. Świadczyć ma o tym fakt, iż przegląd opisanych na przestrzeni ostatnich 25 lat scenariuszy rozwoju pokazuje, że przewidywania dotyczące przyszłości Ziemi tworzone zwłaszcza w latach 70 tych okazały się "nierealne i politycznie kontrproduktywne". Europejska Agencja Ochrony Środowiska, która zleciła badania w tym zakresie dokonała tym samym oceny, której zasadność wydaje się być dyskusyjna. „W ciagu ostatniej dekady została uznana kluczowa rola niepewności. To doprowadzito do zrozumienia, że budowanie scenariuszy to nie zdeterminowany naukowy proces. Scenariusze nie moga przewidywać, ale maluja obraz możliwych przyszłości i przedstawiaja różne rezultaty zwiqzane z pytaniem "jeżeli to co". W literaturze naukowej istnieje różnorodność

17 Meadows, Meadows. Limits to Growth 1972, Beyond the limits, 1991.

18 Publikacje nie tylko osób związanych z Klubem Rzymskim jak Aurelio Peccei, Przyszłośc jest w naszych rękach. PWN, Warszawa 1997. 
Marek Haliniak

definicji scenariusza. Pierwsza i szeroko cytowana to: "Scenariusze to hipotetyczne sekwencje zdarzeń skonstruowane w celu zwrócenia uwagi na proces przyczynowy $i$ punkty decyzyjne". Po pierwsze warto zwrócić uwagę na fakt, że krytykowane dzisiaj przewidywania sprzed ćwierćwiecza formułowane były jako ostrzeżenie polityczne, które aby być skutecznym musiało zawierać elementy skłaniające społeczność międzynarodową do poważnego zastanowienia. Nie jest więc niczym nadzwyczajnym, że obarczone były pewną i zrozumiałą zarówno wówczas jak i dzisiaj przesadą. Po drugie nie wolno ignorować faktu, że właśnie dzięki tamtym ostrzeżeniom praktyka $\mathrm{w}$ zakresie ochrony dziedzictwa naturalnego uległa poważnej zmianie. Nie chodzi tutaj o skalę zanieczyszczeń, czy poziom dewastacji środowiska. Istotnym jest, że szeroka dyskusja prowadzona $\mathrm{w}$ skali globalnej wprowadziła tematykę środowiska na jedno z czołowych miejsc debaty światowej. Należy pamiętać, że trzydzieści lat temu głównym tematem tej debaty był Nowy Międzynarodowy Ład Gospodar$\mathrm{czy}^{19}{ }^{19}$, który w praktyce pomijał zarówno kwestie ekologiczne jak i kwestie społeczne (prawa człowieka). Problem globalny sprowadzano do międzypaństwowej relacji na linii Północ-Południe, a państwa rozwijające się starały się zdominować fora międzynarodowe dla uzasadnienia swoich roszczeń wobec państw rozwiniętych bez jakichkolwiek własnych zobowiązań w odniesieniu do własnych obywateli jak i środowiska naturalnego. Od tego czasu kwestie ekologiczne i społeczne stały się istotnymi elementami międzynarodowych systemów normatywnych (prawa międzynarodowego, moralności międzynarodowej, aksjologii międzynarodowej oraz prakseologii międzynarodowej) ${ }^{20}$. Chociażby ten fakt wskazuje, że ostrzeżenie okazało się skuteczne i wbrew wcześniej zaprezentowanej opinii „politycznie produktywne”. Ponadto należy podkreślić, że istotą praktycznego zastosowania modeli dla tworzenia strategii politycznych jest nie tyle sformułowanie prognozy, która sprawdzi się po kilkudziesięciu latach, lecz ich wprowadzenie jako stałego instrumentu działania politycznego zdolnego do kreowania różnorodnych scenariuszy w zależności od przyjętych założeń oraz wprowadzonych danych. W tym kontekście modelowanie jest przede wszystkim narzędziem umożliwiającym symultaniczną analizę możliwych scenariuszy rozwoju - zarówno tych realizowanych, jak i potencjalnie możliwych. $Z$ punktu widzenia strategii politycznej nie chodzi wyłącznie o to, czy dany scenariusz wystąpi czy też nie, lecz o samą możliwość przewidzenia wystąpienia danych wariantów. Tym samym wyniki pozwalają na stałe określanie

19 Karta Międzynarodowych Praw i Obowiąków Państw w zakresie NMŁG, Rezolucja ONZ, 1975.

20 Pełną typologię systemów normatywnych w stosunkach międzynarodowych przedstawił J. Gilas w pracy Systemy normatywne stosunków międzynarodowych, Toruń, 1985. 
Filozoficzne aspekty modelowania cybernetycznego w metodologii dziatań politycznych...

możliwych wariantów rozwoju wydarzeń oraz na przypisanie prawdopodobieństwa ich wystąpienia w zależności od rozwoju sytuacji.

Co do zasadności samej potrzeby prognozowania posłużę się opinią Cz. Banacha, że "trudności i błędy studiów nad przyszłościa i formułowania prognoz sa znacznie mniejsze od strat wynikajacych z braku myślenia o przyszłości”21 oraz poniższymi fragmentami książki „Przyszłośc świata” Federico de Mayor: "Albowiem naszej krótkowzroczności czasowej towarzyszy jakże często dobrowolne zaślepienie - ta krótkowzroczność stuży niekiedy jego usprawiedliwieniu. Wciagnięci w wir spraw bieżących, ulegając tyranii doraźności, nie mamy czasu na wypracowanie konstruktywnych dziatań i przewidywanie ich konsekwencji. Podażamy bez hamulców i widoczności ku nieznanej przyszłości. A przecież im szybciej jedzie samochód, tym większy powinien być zasięg jego światet. Nie chodzi więc obecnie o dostosowywanie $i$ adaptowanie się, albowiem czas jest zawsze szybszy. Chodzi o to, aby wyprzedzać.(...)Opowiedzmy się za wizja dalekowzroczna, zorientowana ku przyszłości i kierujmy nasze prospektywne spojrzenie na świat. Siejmy dziś ziarna przyszłości, czuwajmy nad ich kiełkowaniem: jutro nasze dzieci zbiora owoce naszej antycypacji. Przewidywać aby zapobiegać, przewidywać aby budować, oto nasz cel. Przewidywanie nie jest tylko możliwościa; jest tez obowiazkiem, imperatywem moralnym. Idea ta utorowała już sobie drogę w świadomości ogótu i w prawie międzynarodowym"22.

Autorzy "Cloudy crystal balls ... scenerio studiem and models" proponują następującą definicję scenariuszy: "Scenariusze to prototypowy opis lub wybrany obraz przyszłości, stworzony z umystowych map lub modeli, które odzwierciedlają różne możliwości przeszłych, obecnych i przyszłych ścieżek rozwoju". Jednocześnie proponują typologię scenariuszy według kryterium czasu (scenariusze przeszłości i przyszłości), scenariusze opisujące i oceniające oraz jakościowe i ilościowe. W tym kontekście modelowanie jest zasadniczym narzędziem tworzenia strategii politycznych, podczas gdy pozostałe stają się narzędziami pomocniczymi. Wynika to z faktu, że jej zastosowanie - dzięki narzędziom cybernetycznym - pozwala na uwzględnienie wielkiej liczby danych oraz rezultatów zastosowania metod wspomagających. Modelowanie społeczne uwzględniające narzędzia cybernetyczne stało się praktycznie możliwe dopiero przy zastosowaniu wystarczająco wydolnych systemów informacyjnych z wykorzystaniem komputerów. W szczególności rozwój technik komputerowych stwarza możliwość radykalnego udoskonalenia efektywności polityki rozwoju społecznogospodarczo- przyrodniczego, w tym polityki ekologicznej. Zastosowanie przy kształtowaniu i ocenianiu następstw tej polityki metod symulacji

21 Cz. Banach, Polska w XXI wieku, (w:) Szkoła w rozwoju, red. J.Kropiwnicki, Jelenia Góra 2000.

22 Federico Mayor, Przyszłośc świata, wyd. Fundacja Studiów i Badań Edukacyjnych, Warszawa 2001. 
komputerowej wielkich systemów społeczno-gospodarczych umożliwia politykowi pozyskiwanie wiedzy niedostępnej tradycyjnymi metodami. Modelowanie obiektów będących przedmiotem polityki wymusza poznawanie licznych współzależności zachodzących pomiędzy elementami tych obiektów, a także dotyczących dalszych relacji - występujących pomiędzy tymi obiektami, a ich środowiskiem społeczno-przyrodniczym. W wyniku symulacji komputerowej przyszłego zachowania się badanych tak obiektów i układów: dany obiekt - środowisko, można uzyskać wiedzę dotyczącą zarówno następstw zmian wprowadzanych $\mathrm{w}$ te obiekty $\mathrm{w}$ wyniku realizacji polityki jak i konsekwencji braku działań usprawniających przebieg zachodzących w nich procesów.

Ostatnie ćwierćwiecze to jednocześnie okres dyskusji dotyczących założeń metodologicznych, jakim odpowiadać powinien model, aby modelowanie działań politycznych spełniało kryterium skuteczności.

\section{Prakseologiczne i aksjologiczne założenia modelu Sage’a}

Doświadczenia programów prognozowania ostrzegawczego pokazały, że warunkiem poprawnego konstruowania modeli, oprócz odpowiedniego poziomu rozwoju technologii informacyjnych jest wiedza systemowo-filozoficzna. Postulat wprowadzenia tej ogólnej wiedzy do metod symulacji komputerowej $\mathrm{w}$ odniesieniu do wielkich systemów sformułował A. P. Sage. Autor ten zaproponował poniższy model kształtowania polityki z zastosowaniem metod wspomagających uwzględniających technologie informacyjne:

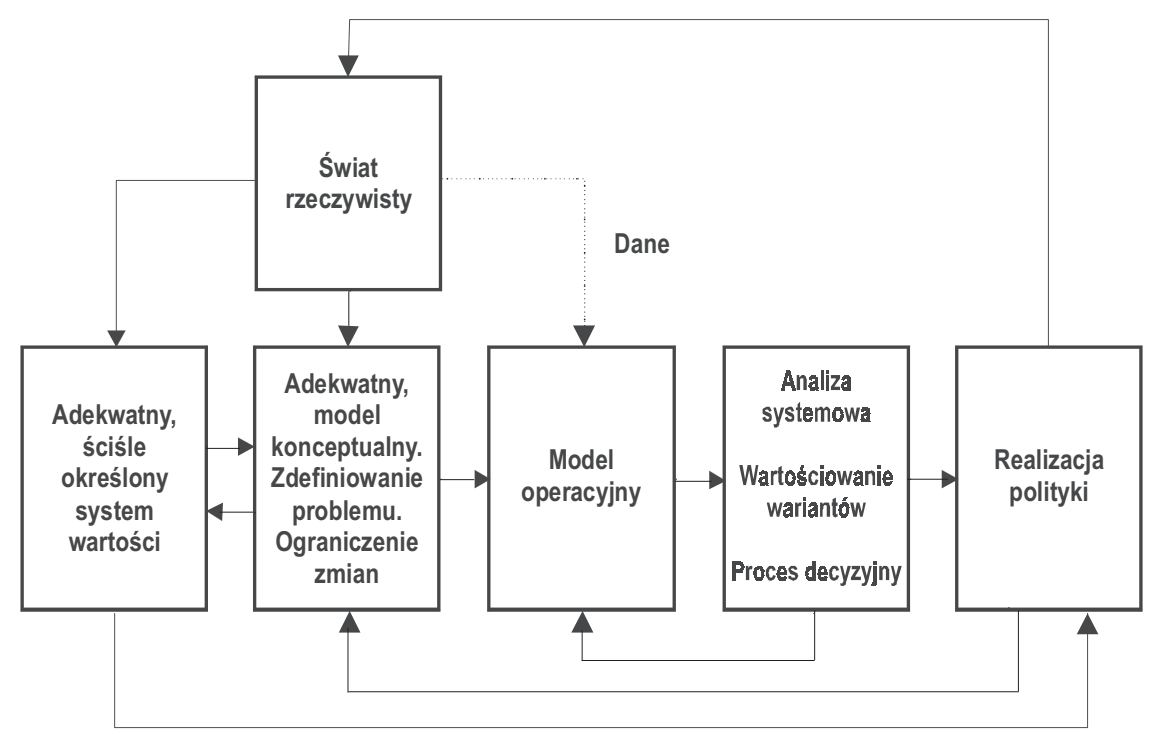


Filozoficzne aspekty modelowania cybernetycznego w metodologii dziatań politycznych...

Można powiedzieć,że A. P. Sage'a strategie polityczne traktuje jako instrument, którego właściwe zastosowanie umożliwia „skuteczne trafienie w szybko przemieszczający się cel"23. Niezbędną podstawą ich prawidłowego formułowania w coraz większym stopniu stają się technologie informacyjne dostosowane do metodologii sterowania wielkimi systemami. Polityka w tym ujęciu to sztuka formułowania celów, których osiąganie umożliwia zaspokojenie potrzeb reprezentowanej społeczności. Jest to także umiejętność doboru i stosowania metod optymalizujących koszty dostosowań. W tym kontekście zrozumiałym jest, iż A.P. Sage negatywnie ocenia proces formułowania polityki w jej społecznym i gospodarczym wymiarze ze względu na fakt, że decydenci pozbawieni są dostępu do niezbędnej wiedzy. Autor w fakcie tym upatruje jedną z przyczyn kryzysów w tych obszarach. Zwraca uwagę, że przy określeniu celów działalności i wartościowaniu jej dokonań nie uwzględniane są obecnie liczne, realnie istniejące, $\mathrm{w}$ tym podlegające zmianom, współczesne uwarunkowania życia i ograniczenia rozwoju. W szczególności ograniczone są możliwości przewidywania, zwłaszcza odległych $\mathrm{w}$ czasie $\mathrm{i}$ przestrzeni, kompleksowych skutków podejmowanych działań. Innymi słowy wartościowanie zamierzeń i osiągnięć jest przeprowadzane z zastosowaniem nieadekwatnego do współczesnej rzeczywistości systemu wartościowania efektywności działalności społeczno-gospodarczej. Jako remedium Sage zaleca zasadnicze zmiany w sposobie informacyjnego wspomagania polityki i dokonywania ocen jej skutków. Funkcjonowanie takiego rozbudowanego systemu kształtowania polityki musi być oparte $\mathrm{o}$ „układ sprzężenia zwrotnego wyprzedzającego" - feed forward. (Prekursorem tego pojecia $\mathrm{w}$ cybernetyce był N.Winer ${ }^{24}$ ). Jako konieczność traktuje również rozbudowanie systemów udostępniania wiedzy optymalizującej decyzje polityczne. Zwraca on jednak uwagę, że podstawą optymalnego kształtowania polityki oraz dokonywania ocen jej wyników jest istnienie adekwatnego do rzeczywistości systemu wartości. Ten swoisty metasystem aksjologiczny pozwalałby na wartościowanie zmian zachodzących i zamierzonych. Postuluje, aby realizowane cele polityczne pozostawały w zgodności z takim systemem wartości.

Określenie podstawowych celów polityki zgodnie z propozycjami Sage'a powinno się dokonywać więc za pomocą adekwatnego do rzeczy-

23 Zob. A.P. SAGE, Methodology for large-scale systems, New York 1977 oraz jego interpretacja w Praktyczne aspekty filozofowania, (współautor: Eulalia SAJdAK-MichnowsKa), [w:] Filozofia w dydaktyce akademickiej, (red.) Eulalia SAJDAK-MichnowsKa, Katedra Filozofii Pomorskiej Akademii Pedagogicznej, Słupsk 2001.

24 N. WIENER, Cybernetyka i spoteczeństwo, Warszawa 1961, oraz Cybernetyka, czyli sterowanie i komunikacja w zwierzęciu i maszynie, Warszawa 1971. 
wistości modelu konceptualnego ${ }^{25}$. Powinien on możliwie szeroko obejmować aktualnie występujące $\mathrm{w}$ rzeczywistości, statyczne i dynamiczne, trwale albo okresowo niezmienne - ograniczenia różnorodności zmian pozostających w zakresie decyzji politycznej.

Konkretne przedsięwzięcia, projektowane dla zaspokojenia pożądanych potrzeb, powinny być zdaniem Sage'a określane za pomocą modelu operacyjnego. Taki operacyjny model komputerowy stanowilby podstawę analizy systemowej, dokonywanej za pomocą technik informatycznych i wiedzy szczegółowej. Za pomocą takiej, komputerowo wspomaganej analizy, ustalać się powinno operacyjne i szczegółowe cele działań, a także kolejność ich osiągania. Za pomocą tego modelu powinno się zgodnie z propozycjami Sage'a - dobierać konkretne metody ich realizacji i wstępnie oceniać prawdopodobne skutki ich zastosowania. Programy operacji, przygotowywane wariantowo, powinny uwzględniać zarówno realnie $\mathrm{w}$ danym czasie występujące różnorodne ograniczenia, jak i prawdopodobne zmiany w uwarunkowaniach realizacyjnych. Decyzje, podejmowane po takim przygotowaniu oraz ich skutki powinny być oceniane, ze względu na stopień zaspokajania potrzeb lub realizacji zakładanych wstępnie celów, za pomocą przyjętego systemu wartości.

Oczywistym warunkiem poprawności tak kształtowanej, testowanej i korygowanej polityki, powinien być odpowiedni dostęp do wiedzy „danych" - czyli informacji odwzorowującej układ: przekształcany przez polityka system - jego bliższe i dalsze otoczenie. Informacji - dotyczącej zarówno zmieniającego się stanu statycznego jak i dynamicznych właściwości przekształcanej rzeczywistości, a więc także informacji o zmianach zachodzących $\mathrm{w}$ stanie tego układu pod wpływem realizowanej polityki lub innych, w tym zewnętrznych, oddziaływań.

\section{Prakseologiczne i aksjologiczne założenia modelu Michnowskiego ${ }^{26}$}

Propozycje Sage'a zostały poważnie rozbudowane i przeniesione na grunt nauki polskiej przez L. Michnowskiego. W oparciu o pojęcie konceptualnego modelu rzeczywistości A. P. Sage'a L. Michnowski stworzył

25 W literaturze trudno znaleźć propozycje takiego modelu. Zwrócili na to uwage Eulalia Sajdak-Michnowska i Lesław Michnowski w referacie, wygłoszonym w dniach 21-22 września 2001 na konferencji nt.: Filozofia w szkole, zorganizowanej przez Zakład Historii Filozofii Akademii Świętokrzyskiej im. Jana Kochanowskiego w Kielcach, oraz Sekcję Nauczania Filozofii Polskiego Towarzystwa Filozoficznego. Referat ten zawiera także założenia na jakich powinien być sformułowany oraz funkcje jakie powinien spełniać model konceptualny.

26 Lesław Michnowski, od roku 1977 wypracowuje systemowo-informacyjną metodę badania uwarunkowań oraz projektowania rozwoju, którą nazwał metodą w ramach cybernetyki roz- 
i zinterpretował model który określił jako „System Życia”. Istotną podstawą jego modelu jest uznanie procesu życia dowolnej postaci systemu życia (sż) jako procesu tworzenia informacji w układzie sż - środowisko, co oznacza w przypadku rozwoju sż - zwiększanie jego poziomu informacji, albo (w przypadku regresu) przeciwstawiania się zwiększaniu poziomu entropii sż. Ułatwia do określanie uwarunkowań i stymulowanie rozwoju poprzez odpowiednie zmiany $\mathrm{w}$ informacyjnej infrastrukturze tych systemów.

Znaczenie modelu Michnowskiego wynika przede wszystkim z faktu, że wydaje się iż model ten może służyć jako uniwersalny instrument kształtowania polityki państwa. W szczególności Michnowski uznał „System Życia" za niezbędny dla prowadzenia - w sytuacji zmian i ryzyka polityki zrównoważonego rozwoju.

Przykład omawianego ogólnego modelu konceptualnego rzeczywistości, w postaci modelu układu: człowiek - technika - przyroda o nazwie System Życia, jest przedstawiony m.in., w pracy pt.: Jak żyć?, Ekoro$z w o ́ j$ albo..., ${ }^{27} \mathrm{~W}$ ujęciu tego modelu systemami życia są m.in. organizm biologiczny, rodzina, naród, światowa społeczność, jej przyrodnicze otoczenie, globalny ekosystem, Universum.

L. Michnowski opracował również ogólne założenia procesualne konceptualnego modelu rzeczywistości odnoszące się do modelu ogólnego. Ogólny konceptualny model rzeczywistości w ujęciu Michnowskiego to model jakościowy, odwzorowujący - na wysokim poziomie abstrakcji podstawowe reguły jej budowy, działania i rozwoju. Model ten służyć ma głównie odzwierciedlaniu istoty, uwarunkowań oraz przebiegu procesów. Istotnym jest nie tylko sam kierunek zmian, lecz również kolejność faz, etapów, a także inne zmiany o charakterze jakościowym. Przetwarzana w oparciu o ten model wiedza jest $\mathrm{w}$ ten sposób identyfikowana i segregowana przede wszystkim z uwzględnieniem trwałych, niezmiennych właściwości i cech strukturalnych rzeczywistości, jak i tych jej właściwości i cech strukturalnych, które podlegają zmianom zgodnie z logiką procesu rozwoju. Jak widać Michnowski postuluje wydzielenie danych ustruktura-

woju, a następnie - cybernetyki ekorozwoju. Praktyczne wnioski dla polityki rozwoju Polski w oparciu o tę metodę zostały przedstawione już w 1990 w L. Michnowski, Jaki model rozwoju? „Wieś i Państwo”, 1990, nr 2-3, s. 12-49. Przykładowo: Działalność gospodarcza jako system informacyjny rozwijający się, „Zarządzanie”, 1977, nr 11. System informacyjny rozwijający się jako pomoc w projektowaniu, (w:) Prace naukowe Instytutu Cybernetyki Technicznej Politechniki Wrocławskiej, nr 53, konferencja nr 18, 1978. System informacyjny rozwijający się jako model rozwoju systemu społeczno-gospodarczego, w: IV Ogólnopolskie Konwersatorium nt.: „Cybernetyka, Inteligencja, Rozwój” CIR'89, ZG PTC i COBNiD w Siedlcach, Siedlce 1989.

27 Patrz: L. Michnowski, Jak żyć? Ekorozwój albo ...,Wyd. Ekonomia i Środowisko, Białystok 1995. 
lizowanych od danych podlegających zmianom pod wpływem tych struktur. Nie oznacza to jednak przyjęcia założenia niezmiennego charakteru struktur. Ogólnym założeniem jest, że odwzorowanie każdego elementu rzeczywistości może prowadzić do zmiany struktur, bez naruszania ogólnych założeń filozoficznych, na podstawie których konceptualny model został oparty. Tym samym widać, że właśnie identyfikacja, selekcja i zastosowanie właściwych założeń filozoficznych jest głównym determinantem metodologicznej poprawności, a co za tym idzie praktycznej użyteczności modelu. Zwrócić należy uwagę, że efektywność modelu Michnowskiego jako narzędzia budowy strategii politycznych wynika również z faktu, że przyjmuje on założenie występowania $\mathrm{w}$ rzeczywistości trwale albo jedynie okresowo niezmiennych ograniczeń różnorodności zmian. Ograniczenia te uniemożliwiają bowiem wprowadzenie, $w$ danym czasie, danej zmiany. $Z$ jednej strony więc model spełnia kryterium efektywności, gdyż odzwierciedla rzeczywistość $\mathrm{w}$ zakresie możliwości, pomijając warianty wychodzące poza przyjęte ograniczenia. Z drugiej strony brak wiedzy o tych ograniczeniach stanowi istotne ryzyko, że działania podejmowane bez wiedzy o tych ograniczeniach okażą się nieskuteczne. Michnowski zaznacza, że wiedza o tych ograniczeniach jest szczególnie istotna wobec chaotycznego przebiegu procesów, a założenie niezmiennego charakteru pewnych elementów chaosu umożliwiać ma wybór alternatywnych wariantów działań w warunkach kryzysów.

Przy założeniu spełnienia tego warunku model Michnowskiego odzwierciedla ogólne właściwości i strukturę różnorodnej postaci systemów i określa ich dynamikę rozwojową w języku cybernetyki - jako powiązanych ze sobą systemów sprzężeń prostych i zwrotnych, podstawowych więzów życia oraz innych współzależności występujących pomiędzy podsystemami lub elementami rzeczywistości. W szczególności model ten ukazuje podstawowe strukturalne, w tym informacyjne, uwarunkowania życia w procesie zmiany.

Postulowany przez Michnowskiego konceptualny model rzeczywistości jest zatem modelem o wysokim poziomie uogólnienia, opartym bezpośrednio na założeniach filozoficznych. Model ten ułatwiać ma rozpoznawanie tych procesów, które nie mogą być rozpoznawane poprzez ekstrapolację i ukazywać jakościowe zmiany w ich przebiegu jako wynik interakcji zmian wewnątrzsystemowych oraz tych zachodzących $w$ uwarunkowaniach zewnętrznych.

Model Michnowskiego może $w$ ten sposób być przydatny zarówno dla analizy procesów historycznych, optymalizacji działań bieżących, a przede wszystkim stać się narzędziem prognozowania i sterowania zmiennością form i uwarunkowań. W szczególności jego zastosowanie pozwoliłoby na optymalizację kolejności podejmowanych działań. 
Filozoficzne aspekty modelowania cybernetycznego w metodologii dziatań politycznych...

Przedstawionym przez Michnowskiego uzasadnieniem celowości, a wręcz konieczności stosowania tak (lub podobnie) zaprojektowanego modelowania jako narzędzia polityki jest wzrost ryzyka związanego z uwarunkowaniami, w jakich funkcjonuje ludzkość. Ryzyko to związane jest przede wszystkim z rozwojem technologii i pojawieniem się szeregu nieznanych wcześniej i potencjalnie niebezpiecznych możliwości. Można dodać, że ryzyka na które wskazuje Michnowski mają charakter - w coraz większym stopniu zewnętrzny wobec człowieka.

Jako warunek wstępny określił zbudowanie adekwatnego do rzeczywistości jej homomorficznego modelu konceptualnego. Ponieważ model taki nie został dotychczas stworzony autor ten uznal, iż przydatne $\mathrm{w}$ realizacji postulatu Sage/a mogą być prace z zakresu cybernetyki rozwoju. Na podstawie przeprowadzonych badań doszedł do wniosku, że przyczyną jest bariera wynikająca $\mathrm{z}$ braku umiejętności eliminacji następstw degradacji moralnej, a tym samym brak zgody na wyznaczenie granic, przekroczenie których byłoby niedopuszczalne. Analiza konceptualnego modelu stworzonego przez L. Michnowskiego ujawnia filozoficzne założenia tego systemu. L. Michnowski przyjmuje, że rzeczywistość (określana przez niego jako współczesne Universum) jest wielkim, hierarchicznie zbudowanym systemem życia - systemem ekospołecznym. Jest to system trójelementowy, na który składają się człowiek - technika - przyroda. Rozwój systemu życia według L. Michnowskiego warunkowany jest rozwojem życia jego otoczenia. Tym samym zależy od jakości i odpowiedniej postaci otoczenia. Istotą życia jest strukturalne dążenie do jego podtrzymywania. Tym samym model nie obejmuje systemów autodestrukcyjnych. System jest ograniczony czynnikiem czasu, co oznacza, że każdy system życia jest skończony. W odróżnieniu jednak od systemów autodestrukcyjnych koniec nie jest strukturalnie zdeterminowany. Wzajemna interakcja systemu życia $\mathrm{z}$ otoczeniem sprowadzona być może do dwóch efektów - pozytywnego (awansowanie) oraz negatywnego (degradacja). W założeniach L. Michnowskiego procesy życia Universum i jego elementów podlegają ich wewnętrznej logice systemowej. W szczególności wszystkie elementy systemu posiadają wspólne homomorficzne właściwości i cechy strukturalne. Chaos ma charakter wewnątrzsystemowy i jest procesem dokonującym się $\mathrm{w}$ ramach obiektywnie istniejących ograniczeń zmian.

W oparciu o powyższe założenia sformułowane zostały podstawowe funkcje konceptualnego modelu rzeczywistości.

Analiza modelu Michnowskiego pokazuje, że powinien spełniać następujące warunki: (1) zwiększać skuteczność prowadzenia polityki (czyli kształtowania przyszłości interesującego fragmentu rzeczywistości) przy ograniczonym dostępie do wiedzy o kompleksowych skutkach działań i 
ich uwarunkowaniach; (2) kierować poznawanie rzeczywistości na problemy podstawowe, zmniejszające niewiedzę i zwiększające sprawność jej poprawnego przekształcania; (3) ułatwiać zrozumienie sposobu funkcjonowania rzeczywistości, a w szczególności modelowanego jej fragmentu; (4) ukazywać podstawowe nieliniowości w przebiegu modelowanego procesu życia, (5) ułatwiać rozpoznawanie trwałych i podlegających okresowym zmianom ograniczeń dokonywania zmian rzeczywistości; (6) umożliwiać konceptualne przewidywanie przyszłości i skutków podejmowanych działań; (7) ułatwiać intuicyjne wspomaganie polityki w przypadku braków w naukowo pozyskiwanej wiedzy o rzeczywistości. Ponadto w ujęciu Michnowskiego model powinien również ułatwiać: (1) określanie podstawowych stanów jakości życia poddawanych oddziaływaniom polityki systemów oraz wewnętrznych lub zewnętrznych uwarunkowań ich powstawania (2) strukturalnych uwarunkowań trwałego rozwoju systemów życia, (3) rodzajów i uwarunkowań występowania patologii procesu życia, (4) morfologii kryzysu systemów życia, (5) zachowań systemów życia w zależności od rodzajów uwarunkowań, (6) zmian $\mathrm{w}$ systemie wartości w zależności od zmian uwarunkowań życia.

Warto podkreślić, iż w odniesieniu do planowania polityki zrównoważonego rozwoju L. Michnowski uznał, że najbardziej efektywne byłoby sformułowanie dwóch sprzężonych ze sobą modeli konceptualnych : (1) ogólnego modelu rzeczywistości obejmującego zarówno całość Universum, jak i jego elementy składowe oraz (2) szczegółowy model rzeczywistości - sprzężony z modelem ogólnym - odnoszący się do danego konkretnego systemu typu: człowiek - technika - przyroda, który podlega bezpośrednim oddziaływaniom prowadzącego politykę. Warto zaznaczyć, iż w opinii Michnowskiego budowa modelu szczegółowego wynikać ma z modelu ogólnego, gdyż tylko w ten sposób możliwe jest zapewnienie filozoficznej spójności systemu.

Ponieważ warunkiem skuteczności działania politycznego jest zbudowanie na zgodnych z rzeczywistością przesłankach (aksjomatach) adekwatnego modelu konceptualnego, Michnowski sugeruje, aby zasadami tymi były na przykład wynikający z II zasady termodynamiki aksjomat dotyczący nieuchronności śmierci cieplnej Wszechświata i oparty na wiedzy cybernetycznej oraz o aktywną rolę świadomości aksjomat realności Punktu Omega Teilharda de Chardin.

\section{Zamiast zakończenia: wnioski}

1. Jedną z blokad wdrażania strategii zrównoważonego rozwoju jest fakt, że przenika głównie poprzez takie systemy normatywne jak moralność, aksjologia czy system norm politycznych bez poświęcania na- 
Filozoficzne aspekty modelowania cybernetycznego w metodologii dziatań politycznych...

leżnej uwagi kwestiom metodologii i prakseologii tworzenia oraz wdrażania politycznych strategii zrównoważonego rozwoju. W szczególności dotyczy to aspektów związanych z modelowaniem cybernetycznym jako instrumentem formułowania strategii politycznych.

2. Ogólną przesłanką przezwyciężenia tej blokady jest prawidłowe zdefiniowanie miejsca cybernetyki w relacji do filozofii oraz poszczególnych dyscyplin szczegółowych. W szczególności istotna jest rola prawidłowego wykorzystania narzędzi cybernetycznych jako instrumentu pozwalającego na poszukiwanie równowagi pomiędzy ujęciami syntetycznymi i analitycznymi $\mathrm{w}$ formułowaniu i ocenie strategii politycznych.

3. Podkreślić należy wzrost znaczenia modelowania jako narzędzia warunkującego prawidłowe (z prakseologicznego punktu widzenia) formułowanie strategii politycznych. Wraz z rozwojem technologii informacyjnych modelowanie może stać się najbardziej skutecznym narzędziem działania politycznego. $Z$ tej perspektywy istotne są filozoficzne założenia budowy modelu konceptualnego. Postuluje się, aby przedmiotem analizy filozoficznej były założenia modeli. Najbardziej interesujący pod tym względem wydaje się być model L. Michnowskiego.

\section{The Philosofical aspects of cybernetic modelling in methodology of sustainable development policy}

\section{SUMMARY}

The article deals with the experience and results of attempts aimed at using cybernetic system methods for modeling the policy of the sustainable development. The analyze is made from the ecophilosophical perspective. The cybernetics is presented as the sub-philosophical, general and inter-disciplinary science with a high level of influence on process of policy-making and policy-makers. However the barriers of philosophy and cybernetics in that respect are strictly connected with the limits of philosophy. The question concerns the problem of transferring the ideas into practice by the method of cybernetic modeling. Whereas the conceptual model should reflect the objective reality it should be based on some general, politically accepted ideas. This necessity is obvious because of the link between the basic axioms of a given model with the general results generated by it. The author analyses the possibility of appliance the Sage-Michnowski model as the instrument for planing the sustainable development policy as the interrelated social, economical and ecological system. 